\title{
PERAN INFOMASI DIGITAL DALAM PEMBELAJARAN MEMBACA PADA MATERI TELAAH SASTRA DI PERGURUAN TINGGI
}

\author{
${ }^{1}$ Denik Wirawati, ${ }^{2}$ Hasrul Rahman \\ ${ }^{* 1,2}$ Pendidikan Bahasa dan Sastra Indonesia, Fakultas Keguruan dan Ilmu Pendidikan, \\ Universitas Ahmad Dahlan, Indonesia \\ e-mail: 1denik@pbsi.uad.ac.id, 2hasrul.rahman@pbsi.uad.ac.id
}

\begin{abstract}
ABSTRAK
Penelitian ini memiliki tujuan menjabarkan proses pembelajaran yang menggunakan informasi digital, proses pembelajaran ini pada masa pandemic covit 19. Salah satu mata kuliah yang dijabarkan menggunakan teknologi digital adalah kelas keterampilan pada ranah keterampilan membaca. Keterampilan membaca pada materi membaca telaah sastra merupakan salah satu yang membutuhkan peran informasi digital. Dalam penelitian ini menjabarkan keterkaitan peran informasi digital dalam proses pembelajaran. Mahasiswa lebih antusias dalam proses pembelajaran membaca telaah sastra dengan melibatkan teknologi di dalamnya. Pandemic covit sangat berpengaruh dalam dunia Pendidikan khususnya dalam proses belajar. Sehingga didalam penelitian ini mengangkat peran digital seperti beberapa aplikasi yang menjadi solusi kesulitan proses belajar dan untuk mengatasi kejenuhan. Dunia Pendidikan akan maju apabila peran pengajar besar dalam meningkatkan proses pembelajaran yang lebih menyenangkan. Hasil dari penelitian ini adalah respon positif dari mahasiswa terhadap teknologi yang dipakai dalam proses belajar. Dengan teknologi ini dosen juga akan lebih mudah menyampaikan materi dan evaluasi. Evaluasi bisa lebih cepat dalam melihat hasil nilai yang sudah dikerjakan mahasiswa. Dunia Pendidikan di era 4.0 ini tidak akan lepas dari teknologi, oleh sebab itu peran digital sangatlah penting.

Kata kunci: Peran informasi digital, pembelajaran membaca, telaah sastra.
\end{abstract}

\begin{abstract}
This study describes the role of digital information in the learning process during the Covit 19 pandemic. One of the courses described using digital technology is a skill class in the realm of reading skills. Reading skills in literature review reading material is one that requires the role of digital information. This study describes the relationship between the role of digital information in the learning process. Students are more enthusiastic in the process of learning to read literature by involving technology in it. The COVID-19 pandemic is very influential in the world of education, especially in the learning process. So that in this study the role of digital is raised such as several applications that are a solution to the difficulties of the learning process and to overcome boredom. The world of education will progress if the role of teachers is large in improving the learning process that is more enjoyable. The result of this study is a positive response from students to the technology used in the learning process. With this technology, lecturers will also find it easier to deliver material and evaluate. Evaluation can be faster in seeing the results of grades that have been done by students. The world of education in this 4.0 era will not be separated from technology, therefore the role of digital is very important.
\end{abstract}

Keywords: Role of digital information, learning to read, study literature.

\section{PENDAHULUAN}

Kondisi Indonesia dan beberapa negara mengalami Pandemi covid-19 dan hal ini sangatlah berpengaruh terhadap dunia pendidikan. Pengaruh tersebut yang sangat jelas terlihat pada kegiatan perkuliahan. Perkuliahan yang biasanya dilakukan dengan bertemu langsung (offline) dan sekarang ternyata digantikan dengan system (online). Kondisi yang demikianlah menjadi suatu hal yang menantang di beberapa sektor terutama di dunia pendidikan. Dunia memasuki era industry 4.0 menegaskan bahwa teknologi telah memiliki suatu posisi yang penting dalam berbagai hal [1]. Kondisi inilah yang terjadi pada saat ini, perkembangan dunia Pendidikan sedang berusaha bangun dalam inovasi, terutama dalam pengembangan model pembelajaran, perangkat, supaya materi yang disampaikan secara online dapat dipahami oleh peserta didik.

Mahasiswa berperan aktif dalam menyerap materi yang disampaikan dosen, karena dosen berperan sebagai fasilitator, dinamisator serta motivator dalam proses belajar mengajar, sedangkan keaktifan mahsiswa dibutuhkan dalam pemahaman yang komprehensif [2]. Hal inilah 
yang sangat perlu dipahami kerjasama antara dosen dan mahasiswa dalam menciptakan pembelajaran yang maksimal. Memaksimalkan peran dosen dan memaksimalkan peran mahasiswa, dua komponen ini harus aktif didukung dengan media dalam pembelajaran, sehingga diharapkan ilmu yang tersampaikan dapat dipahami secara maksimal.

Salah satu media dalam mempermudah pembelajaran bagi mahasiswa adalah media internet. Pada umumnya mahasiswa mengakses internet apabila mencari informasi terkait tugas maupun perkuliahan. Media digital merupakan sarana pembelajaran yang tepat pada masa pandemic covit ini. Media digital merupakan jembatan utama dari proses belajar mengajar mentransfer ilmu, melakukan aktivitas perkuliahan dan mempraktikkan ilmu. Sebagai seorang pengajar, pengembangan pembelajaran dengan memanfaatkan digital sangatlah membantu, selain sebagai media mentransfer ilmu, juga media digital merupakan solusi dari tingkat kebosanan siswa.

Membaca merupakan salah satu dari lima keterampilan berbahasa. Di dalam Perguruan Tinggi, mata kuliah membaca diberikan sebagai salah satu kelas keterampilan Bahasa. Pendidikan Bahasa dan Sastra Indonesia Universitas Ahmad Dahlan membagi keterampilan membaca menjadi dua semester. Pada semester pertama (I) matakuliah ini diberi nama komprehensi tulis (membaca I), yaitu terkait dasar dari teori membaca. Kemudian pada semester dua diberikan kajian lebih mendalam terkait praktik membaca dengan nama mata kuliah membaca kritis dan kreatif (membaca II). Masing-masing mata kuliah ini memiliki bobot dua sks.

Salah satu kesulitan dalam kelas keterampilan membaca adalah ketika sudah menjalankan praktik, praktik biasanya dilakukan tatap muka dengan pendampingan langsung, namun dalam kondisi pandemic Covit 19 ini, pengajar diberi keleluasaan menggunakan metode daring. Saat offline atau kuliah tatap muka, dosen bisa menggunakan media baca seperti koran cetak, majalah atau novel untuk praktik langsung dikelas. Pandemi covit membuat seorang pengajar berinovasi dalam menyampaikan kelas praktik. Salah satu inovasi itu dengan memanfaatkan Informasi digital. penerapan pemanfaatan informasi digital ini dijabarkan sebagai salah satu luaran penelitian terkait mata kuliah membaca kritis dan kreatif. Dalam tulisan ini yang dijabarkan sebagian kecil terkait praktik daring membaca kritis dan kreatif khususnya pada materi telaah Bahasa yang kemudian saya persempit terkait telaah Bahasa dan sastra khususnya pada telaah sastra. Tujuan penelitian ini adalah menjabarkan peranan teknologi digital dalam pembelajaran membaca khususnya materi telaah sastra pada perguruan tinggi.

\section{METODOLOGI PENELITIAN}

Peranan teknologi digital dalam penelitian ini merupakan jenis kualitatif dengan menggunakan metode deskriptif. Menurut Afrizal, penelitian kualitatif yaitu system pengumpulan serta cara menganalisisnya dengan mendeskripsikan berupa penjabaran kata-kata baik itu dalam bentuk lisan atau tulisan [3]. Menurut Afrizal, penelitian kualitatif dititik beratkan pada perspektid teoritis yang dipakai oleh peneliti [3]. Menurut Sugiyono, penelitian kualitatif yang menjadi sebuah instrument dan juga alat penelitian adalah peneliti itu sendiri, disini dititik beratkan pada wawasan peneliti [4].

Teknik pengumpulan data merupakan langkah yang strategis untuk mendapatkan data [4]. Dalam penelitian ini metode dan tekniknya dengan kegiatan observasi terlibat, setelah itu memakai dokumentasi, melakukan wawancara kepada mahasisws, membagikan questioner dalam bentuk goglee dokumen. Subjek dalam penelitian ini yaitu bahan ajar telaah sastra. Kemudian objek penelitiannya yaitu pemanfatan informasi digital.

Prosedur penelitian atau bias dikatakan sebagai tahapan-tahapan penelitian yaitu; tahap persiapan, pelaksanaan, dan tahap akhir. Pada tahap persiapan, dosen mempersiapkan RPS, bahan ajar matakuliah membaca yaitu membaca kritis dan kreatif. Tahap pelaksaan dapat dijabarkan sebagai proses dilapangan yaitu melakukan pengamatan satu kelas dengan jumlah mahasiswa 23. Pengamatan ini dengan melaksanakan pembelajaran terkait teori membaca, menyampaikan evaluasi, yaitu berupa tanya jawab. Tahap terakhir yaitu peneliti melakukan pengolahan data hasil observasi. 
Waktu berlangsung kurang lebih tujuh bulan dari turunnya kontrak penelitian. Pelaksanaan penelitian secara daring (online). Tempat dilakukan observasi daring di kelas dengan pengamatan untuk satu sampai dengan dua kelas mata kuliah membaca kritis dan kreatif yang berjumlah kurang lebih 26 mahasiswa.

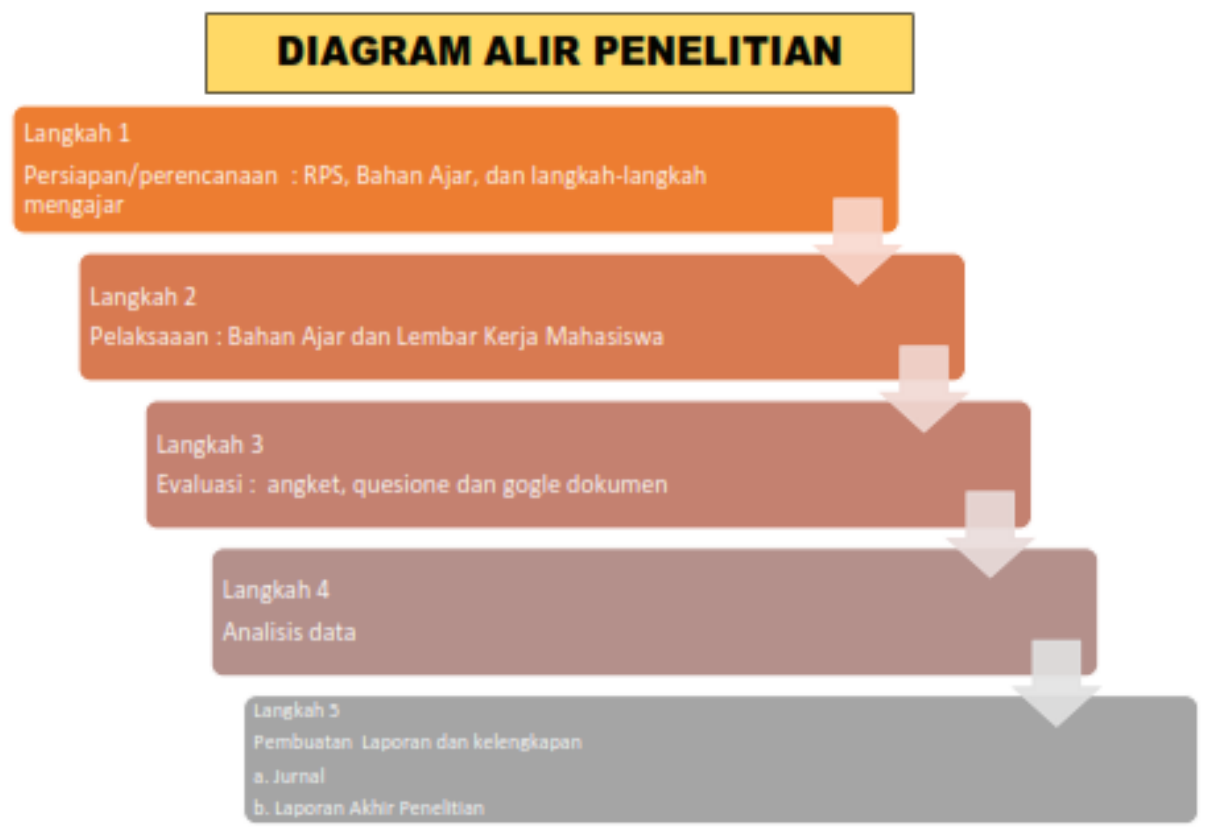

Gambar 1. Diagram Alir Penelitian

Diagram alir penelitian memiliki beberapa langkah yaitu sebagai berikut.

1. Langkah pertama yaitu persiapan. Tahap ini menyiapkan RPS pembelajaran matakuliah membaca kritis dan kreatif, bahan ajar serta langkah-langkah mengajar.

2. Tahap kedua yaitu pelaksaan. Tahap pelaksaan yaitu pemberian materi dan lembar kerja mahasiswa yang beripa gogle form karena masih masa pandemi sehingga melalui daring.

3. Langkah ke 3 yaitu memberikan angket terkait materi dalam bentuk gogle dokumen.

4. Tahap ke empat adalah menganalisis hasil angket yang telah diisi oleh mahasiswa.

5. Tahap terakhir pelaporan hasil penelitian dan jurnal.

\section{HASIL DAN PEMBAHASAN}

Hasil dan pembahasan terkait tahapan dalam pelaksanaan pengambilan data hingga mengolah data yaitu sebagai berikut.

1. Tahap Persiapan

a. Persiapan RPS

Proses belajar di dalam kelas (Perguruan Tinggi) tidak bisa lepas dari acuan proses pembelajaran yaitu berupa RPS. Menurut Sitepu, penyelenggaraan Pendidikan didasarkan pada kurikulum yang ditetapkan dalam standar isi pendidikan nasional. Tertuang dalam Peraturan Menteri Riset, Teknologi dan Pendidikan Tinggi (Permenristekdikti), No. 44 Tahun 2015, terkait dengan adanya Standar Nasional Pendidikan Tinggi. Disini dijelaskan bahwa kurikulum dimaknai sebagai "Seperangkat rencana dan pengaturan mengenai capaian pembelajaran lulusan, juga sebagai bahan kajian, proses, dan penilaian yang digunakan sebagai pedoman penyelenggaraan program studi" yang dikembangkan menjadi Rencana Pembelajaran Semester (RPS) [5].

Mata kuliah ini dilaksanakan empatbelas kali tatap muka (pertemuan) secara daring. Dengan tujuan mahasiswa dapat membangun cara berpikir dan menganalisis gagasan dalam 
bacaan (penekanan praktik membaca). Ditegaskan oleh Dalman bahwa tujuan dari sebuah pembelajaran merupakan bagian penting dari proses itu sendiri [6]. Seperti disampaikan oleh Pradoko bahwa pedagogi kritis memiliki peran besar dalam kaitannya mengubah lingkungan sosial, ekonomi dan juga sector Pendidikan [7]. Hal tersebut memungkinkan seseorang dalam berpikir divergen berkaitan dengan sebab akibat [8]. Dalam 14 kali pertemuan terdiri dari beberapa materi; membaca intensif, dalam membaca intensif mempelajari terkait SQ3R, ECOLA, dan PreP. Pada tulisan ini saya jabarkan sebagian dari penelitian yaitu terkait dengan perkulihan membaca sastra. Materi membaca sastra ini tidak sekedar teori namun juga praktik membaca.

RPS dalam mata kuliah membaca ini memiliki bobot penilaian yang dapat dirincikan sebagai berikut. $10 \%$ merupakan presensi kehadiran, jadi mahasiswa kurang lebih harus hadir sebanyak minimal 12 kali tatapmuka, $20 \%$ berupa tugas baik itu tugas tertulis maupun lisan, 30 $\%$ ujian tengah semester, dan yang terakhir ujian akhir menduduki prosentase sebanyak $40 \%$. Pada materi membaca telaah Bahasa dibagi menjadi dua yaitu telaah Bahasa dan sastra. Fokus tulisan disini menjabarkan perkuliahan materi membaca telaah sastra.

b. Persiapan bahan ajar

Pada masa pandemi covit, proses pembelajaran dilakukan dengan daring, melalui aplikasi GogleeMeet, goglee classroom dan aplikasi Whassatp kelompok. Pemberian materi tetap memakai PPT. Teknologi Informasi pada masa sekarang merupakan salah satu jembatan pembelajaran yang menyenangkan. Dengan memanfaatkan komputer, leptop, gawai seperti disampaikan oleh Juditha bahwa salah satu sarana mencapai tujuan pembelajaran adalah dengan memanfaatkan media digital[9]. Menjadi guru harus memesona pada abad 21 ini karena menciptakan pembelajaran yang menyenangkan adalah modal penting kesuksesan di era teknologi [10]. Teknologi yang sederhana seperti goglledokumen, goglee form, gogleeclassroom dan whasstap sangat membatu.

Salah satu faktor pengajar menggunakan bahan ajar sederhana yaitu pertimbangan kemampuan jaringan dan tingkat kemudahan bagi siswa. Pada tahap persiapan bahan ajar ini sangatlah penting terkait dengan proses yang akan dilaksanakan dilapangan. Tentu saja diharapkan dapat tercapainya pembelajaran merupakan wujud dari proses perkuliahan [11].

Whasstap digunakan sebagai media komunikasi dengan mahasiswa membagikan link/ tautan penghubung GogleeMett. Bahan ajar berupa PPT terkait materi membaca sastra dibagikan menggunakan media GogleeMeet. Terakhir adalah evaluasi menggunakan gogleeform yang dibagikan melalui PPT serta tautan dalam Whassatap kelompok.

c. Langkah-langkah Mengajar

Langkah pertama yaitu dosen memberikan informasi tautan sebagai penghubung komunikasi Goglee Meet, melalui whasstap kelompok. Setelah mahasiswa dapat masuk ruangan perkuliahan daring gogleemeet, seluruh mahasiswa dianjurkan untuk membuka kamera seperti kondisi kuliah tatap muka langsung. Menurut Astini dalam Juniartini yaitu bentuk proses penyampaian bahan ajar kepada peserta didik dalam pembelajaran daring, bisa diakses kapanpun media internet [12] .

Langkah ke dua, dosen membuka kegiatan dengan melakukan doa Bersama. Dosen memberikan salam sapaan serta tidak lupa untuk menanyakan kabar kepada mahsiswa. Seorang dosen wajib menyampaikan RPS yang terkait dengan materi pertemuan tersebut. Untuk mahasiswa menonaktifkan spiker dan tetap membuka kamera, memencet tombol tangan apabila ingin bertanya, hal ini berfungsi sebagai salah satu faktor fokusnya pembelajaran.

Langkah ke tiga yaitu inti dari pelaksanaan kuliah, dosen memulai menyampaikan penyegaran dengan memberi waktu 10 menit kepada mahasiswa untk membaca, hal ini sebagai salah satu wujud menggerakkan literasi baca pada mahasiswa. Dosen perlu mengaktifkan mahasiswa dengan memberikan pancingan tanya jawab. Berdiskusi kecil sebagai salah satu caracara untuk mengingat beberapa materi yang dah lampau.

Ke empat yaitu dosen menayangkan materi PPT dalam layar utama, terkait materi perkuliahan yang digunakan sebagai pendamping proses perkuliahan. Dosen memberikan waktu dan juga memberikan kesempatan untuk tanya jawab. Terakhir dosen memberikan evaluasi. Proses evaluasi memakai media goglleform yang berada dalam goglleclassroom. 
2. Tahap Pelaksanaan

a. Proses Pembelajaran Memakai Goglee Meet

Aktivitas perkuliahan di kelas memakai sarana atau media Goglee meet sebagai cara penyampaian materi membaca sastra. Pembelajaran disesuaikan dengan RPS yang ada sebagai patokan kegiatan. Pertama dosen memulai dengan curah pendapat mengenai materi membaca sastra, hal ini merupakan wujud dari komunikasi antara dosen dan mahasiswa. Membangun kedekatan dengan tanya jawab di dalam komunikasi sangatlah diperlukan dikelas keterampilan.

Materi membaca sastra dilakukan sebanyak dua kali pertemuan, yaitu pada pertemuan pertama diskusi terkait materi membaca sastra kemudian dilanjutkan dengan praktik serta evaluasi. Terkait perkuliahan pertama menggunakan media aplikasi Gogleemeet dengan memberikan materi PPT yang di susun menggunakan beberpa sumber terkait membaca sastra. Sumber utama dari materi ini menggunakan buku Prof. Tarigan dengan judul membaca sebagai sebuah keterampilan berbahasa yang sudah sangat familiar.

Deskripsi tahapan perkuliahan dengan dosen membuka perkuliahan membaca doa, kemudian seperti pertemuan-pertemuan biasanya dimulai dengan membiasakan diri membaca pada mahasiswa. Mahasiswa diberi waktu 10 menit untuk membuka gawai dan mengakses internet. Pada pertemuan ini dosen memberikan arahan terkait membaca cerpern yang terbaru dengan akses internet pada gawai masing-masing mahasiswa. Dengan system ini, mahasiswa belajar memanfaatkan gawai untuk menjadi proses bagian pembelajaran. Setelah membaca, dosen memberikan pertanyaan terkait dengan hasil yang dibaca (cerpen) melalui internet media gawai.

Menggunakan goglee meet sebagai proses belajar di perkuliahan daring merupakan salah satu solusi pembelajaran dimasa pandemi. Adapun beberapa keunggulan dalam menggunakan gogleemeet sebagai pembelajaran daring di perkuliahan adalah; a. dosen dan mahasiswa dapat berinteraksi langsung dengan kelengkapan video, suara, sehingga ketika mahasiswa akan bertanya atau menyampaikan pendapat bisa langsung disampaikan dengan menekan tombol angkat tangan, $b$. dosen dapat dengan mudah membagikan materi dalam bentuk PPT atau video dan mahasiswa mampu langsung menangkap layar, c. aplikasi ini juga sangat fleksibel karena dapat di unduh melalui gawai tidak harus memakai leptop, d. karena fleksibelnya aplikasi ini, mahasiswa dapat mengikuti perkuliahan dimana saja.

Beberapa kelebihan disebutkan di atas, namun bukan berarti aplikasi ini sepenuhnya sempurna, adapun kelemahan dalam sistem aplikasi goglee meet ini adalah; a. system aplikasi ini menggunakan jaringan sebagai system kendali, sehingga banyak beberapa mahasiswa mengalami kendala jaringan karena posisi letak berada di tempat yang jauh jangkauan dari internet, b. goglee meet bisa mati secara tiba-tiba karena kendala signal dan kuota habis, c tidak maksimalnya interaksi pada beberpa matakuliah seperti perkuliahan praktikum yang membutuhkan interaksi langsung dikelas sebagai wujud komunikasi dan pengecekan evaluasi, d. dosen yang harusnya langsung dapat mengoreksi dan menunjukkan kekeliruan pada beberapa evaluasi akan terhambat karena menggunakan system daring, e. gangguan kebisingan sekitar karena terlalu fleksibel perkuliahan, tidak terfokus diruang kelas khusus, dan f. kurang pahamnya teknologi mengakibatkan kesuliatan dalam proses akses dan belajar daring.

b. Proses evaluasi

Setelah proses belajar berlangsung maka dosen memberikan evaluasi terkait membaca sastra melalui gogleeform yang sudah disiapkan beberapa pertanyaan. Dosen memberikan Salinan tautan link goglee classroom guna mengerjakan evaluasi. Memasukkan bacaan cerpen terkait materi membaca sastra dalam gogleeclassroom. Setelah itu terdapat evaluasi soal yang disajikan di bawah bacaan cerpen.

Penelitian ini menggunakan salah satu novel dari karya sastrawan perempuan yaitu Evi Idawati yang sangat dikenal didunia sosial media, pemilihan ini di dasarkan pada kesesuaian usia mahasiswa dengan karya-karya Evi Idawati. Selain itu sebagai kebaharuan teknologi yang mengikuti jaman. Karya-karya Evi sudah di posting di internet sehingga mahasiswa dengan sengaja dan wajib mengakses teknologi internet sebagai beroleh informasi terkait karya-karya penulis tersebut. 
Evaluasi perkuliahan membaca sastra memakai teknologi digital berupa whastap grup, goglee drive, goglee class romm, goglee form. Diberikan wacana cerpen dengan judul Paras Kegaiban karya sastrawan wanita Evi Idawati. Terkait dengan evaluasi membaca sastra menghasilkan data sebagai berikut; 10 soal diberikan dengan membagi dalam tiga kelompok. Pertama terkait dengan unsur intrinsik karya sastra yang meliputi; tokoh, penokohan, latar, amanat, alur, sudut pandang, dan pesan moral dalam cerpen tersebut. Terkait jawaban soal unsur intrinsik hampir 95\% mahasiswa dapat menjawab disertai alasan yang memiliki kemiripan jawaban. Mahasiswa mampu menemukan tokoh, penokohannya, latar dari cerpen, amanat, sudut padang bahkan pesan moral yang ada dalam cerpen Paras Kegaiban tersebut. Salah satu contoh soal terkait sudut pandang, mahasiswa mampu menjawab 97\% dengan alasan rata-rata "karena sudut pandang ini menggunakan "aku" sebagai penyebutan tokoh utama.

Evaluasi membaca sastra terkait cerpen tersebut juga dihubungkan dalam kehidupan sehari-hari. Hal ini dimaksudkan supaya mereka belajar berfikir kritis terhadap kehidupan sekitarnya. Hamper 90\% mahasiswa dapat menjawab dan menghubungkan dengan kehidupan sekitar. Salah satu contoh yaitu dengan pertanyaan; apakah dalam kehidupan sehari-hari Anda menemukan yang mirip cerita tersebut? Dan sebagian mahasiswa rata-rata menjawab dengan jawaban ada, memberikan contoh dalam kehidupan sehari-hari yang mirip dengan cerita tersebut.

Terkait dengan evaluasi teknologi, mahasiswa memberikan apresiasi terhadap model pembelajaran menggunakan teknologi. 89\% mahasiswa menyatakan bahwa pembelajatran menggunakan teknologi merupakan hal yang menarik. Adapun alasan yang disampaikan mahasiswa antara lain; a. mahasiswa menjadi belajar menerapkan teknologi dalam pembelajaran, b. merupakan model pembelajaran yang menarik dalam kondisi pandemic, c. lebih efektif sertacepat, dan, d. dapat mengurangi rasa kebosanan.

\section{SIMPULAN}

Penerapan teknologi di masa pandemi covid merupakan kebutuhan pokok. Dengan adanya teknologi ini, mempermudah proses belajar mengajar dalam penyampaian dan penerimaan materi secara daring. Hal ini terutama terkait perkuliahan kelas keterampilan yang membutuhkan praktik. Penggunaan teknologi goglee drive, goglee meet, gogleeform, gogleeclass dalam pemnbelajaran membaca khususnya materi membaca sastra merupakan salah satu solusi. Proses penerapan teknologi ini mampu mengembangkan kemajuan dalam dunia Pendidikan.

\section{REFERENCES}

[1] M. Sagita and Khairunnisa, "Pemanfaatan E-Learning Bagi Para Pendidik di Era Digital 4.0 Utilization of E-Learning For Educators In Digital Era 4.0," J. Sos. Hum., vol. 2, no. 2, pp. 1-7, 2019.

[2] R. Setiyani, "Pemanfaatan Internet Sebagai Sumber Belajar," J. Pendidik. Ekon. dan Din. Pendidikan-3, vol. 2, pp. 117-133, 2010, [Online]. Available: https://media.neliti.com/media/publications/61217-ID-pemanfaatan-internet-sebagaisumber-bela.pdf.

[3] Afrizal, Metode Penelitian kualitatif. Depok: Rajagrafindo Persada, 2019.

[4] Sugiyono, "Metode Penelitian Kuntitatif, Kualitatif dan R\&D," 2016.

[5] B. P. Sitepu and I. Lestari, "Pelaksaaan Rencana Pembelajaran Semester Dalam Proses PPembelajaran di Perguruan Tinggi," Perspekt. Ilmu Pendidik., vol. 32 No 2, 2018, doi: https://doi.org/10.21009/PIP.321.6.

[6] Dalman, Keterampilan Membaca. Jakarta: Grafindo Persada, 2017.

[7] S. dan A. M. S. Pradoko, Pedagogi Kritis Bagi Dunia Pendidikan. Yogyakarta: Charissa Publisher, 2018.

[8] E. T. Priyatni, Membaca Sastra dengan Ancangan Literasi Kritis. Jakarta: Bumi Aksara, 2012. 
[9] S. A. dan C. Juditha, Media Digital dan Perubahan Budaya Komunikasi. Yogyakarta: Aswaja Presindo, 2019.

[10] N. Hidayat and H. Khotimah, "Pemanfaatan Teknologi Digital Dalam Kegiatan Pembelajaran," JPPGuseda | J. Pendidik. Pengajaran Guru Sekol. Dasar, vol. 2, no. 1, pp. 10-15, 2019, doi: 10.33751/jppguseda.v2i1.988.

[11] A. Syukur Ghazali, Pembelajaran Katerampilan Berbahasa dengan Pendekatan Komunikatif Interaktif. Bandung: Refika Aditama.

[12] N. Juniartini and I. Rasna, "Pemanfaatan Aplikasi Google Meet dalam Keterampilan Menyimak dan Berbicara untuk Pembelajaran Bahasa Pada Masa Pandemi Covid-19," J. Pendidik. dan Pembelajaran Bhs. Indones., vol. 9, pp. 133-144, 2020, [Online]. Available:

https://ejournalpasca.undiksha.ac.id/index.php/jurnal_bahasa/article/view/3537/pdf. 